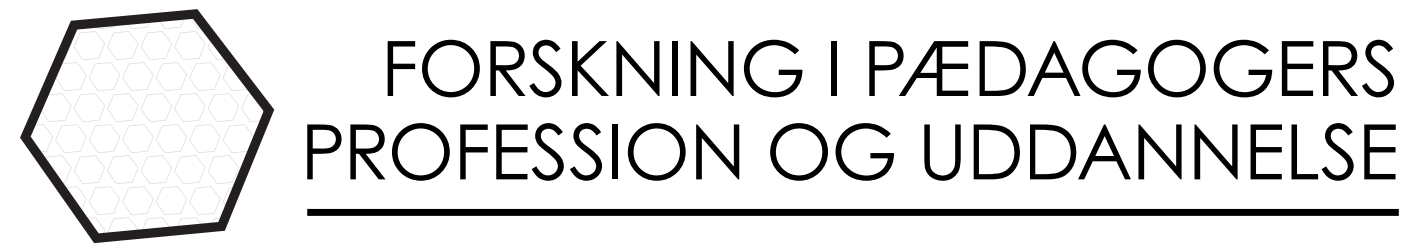

\title{
Om modstand, frihed og myndigblivelse i daginstitutionen
}

\section{Line Togsverd, Jan Jaap Rothuizen, Hanne Hede Jørgensen, Stephan Weise} Lektorer ved VIA UC lto@via.dk 


\title{
Resumé
}

I denne artikel udfoldes et pædagogisk begreb om modstand, der tager udgangspunkt i et forskningsprojekt, hvor vi, sammen med pædagogerne selv, har undersøgt pædagogers fortællinger om praksis, for at komme på sporet af deres forståelser af god pædagogik. Med afsæt i det empiriske materiale og teoretisk støtte i den pædagogiske opdragelsesfilosofi viser vi, hvordan barnets erfaringer med at opleve og komme overens med modstand, forstås som et produktivt og essentielt anliggende i daginstitutionspædagogikken. Artiklen giver indblik i en betydelig kompleksitet og dynamik forbundet med den måde, pædagogerne forstår og fortolker den pædagogiske opgave, det er, at støtte børnene i at engagere sig i en verden og et fællesskab og samtidig blive sig selv. Vi viser, hvordan pædagogernes fortolkninger har resonans i kulturelt overleverede pædagogiske narrativer om betydningen af at arbejde med barnets vilje, og udlæser et begreb om myndigblivelse, der ikke har fornuften som grundtone, men snarere det at ville sin vilje. Dermed peger artiklen på, at pædagoger opererer med en fortolkning og forståelse af god pædagogik, der er i samklang med Dagtilbudslovens brede formål om opdragelse til demokrati og selvstændiggørelse.

\begin{abstract}
About resistance, freedom and coming of age in early childhood education. In order to get an insight in the knowledge early childhood educators bring into play in their daily practices, we have explored about 200 stories from everyday life in Danish Day Care Institutions in collaboration with the pedagogues. What struck us in the analysis of the stories was that the pedagogical importance of resistance was repeatedly mentioned in the pedagogues search for realizing "good pedagogy" in everyday-life. The article points to pedagogues engagements in dealing tactfully with the resistance children encounter as a concern for children's being in the world, more specifically: children's ability to make themselves at home in the world (Cleary \& Hogan, 2001; Gadamer, 2000). The article argues that engaging in such resistance in tactful ways is also a concern for a formation of the child's will, enabling the appearance of the child's subjectivity and the realization of promising children's communities.
\end{abstract}

\section{Nøgleord}

Daginstitutionspædagogik, myndiggørelse, modstand, selvstændiggørelse, selvopdragelse 


\section{Indledning}

Vi får en fortcelling om de nye krus, som Anders (lederen) har købt til institutionen, og som der er meget ballade omkring. Kopperne har alle sammen forskellig farve, men de er ikke alle lige eftertragtede. De lyserøde vil alle pigerne have. Så de prøver at få dem-f.eks. hvis de får lov at doekke bord, så stiller de de lyserøde kopper ved deres pladser, og så sidder de og siger: "jeg fik bare den lyserøde" til hinanden. Carsten (pcedagog) fortceller, at han simpelthen bytter rundt på dem. Han fortceller pigerne, at hvis de tager de lyserøde til sig selv, så bytter han rundt. De to taler om at konflikter er en god ting. De rummer stof til udvikling, til at man kan loere noget om sig selv og om at håndtere sig selv $i$ et fcellesskab. (Feltnote, indledende besøg $i$ institution A)

Den lille feltnote ovenfor stammer fra et forskningsprojekt, hvor vi har interesseret os for, hvad pædagoger lægger vægt på og tillægger betydning, når de gennem deres handlinger fortolker situationer og træffer valg (Togsverd, Jørgensen, Rothuizen, \& Weise, 2017). Vi har i samarbejde med ledere og pædagoger i 5 daginstitutioner udforsket pædagogers egne fortællinger om og udlægninger af, hvordan de har handlet. Vi har antaget, at disse fortællinger om handlinger og valg rummer en pædagogisk viden, en viden om god pædagogik, der kan give pædagogernes handlinger retning. Selvom denne praktiske og retningsgivende viden hverken er entydig eller til at sætte på formel, har vi antaget, at den er betydningsfuld at forstå og udlægge analytisk. Både for at man kan komme til at diskutere den, men også for at pædagogprofessionen selv kan drage omsorg for sin praksis, faglighed og vidensgrundlag.

\section{Modstand som pædagogisk tema}

I vores empiriske materiale kan vi konstatere, at pædagoger ofte fortæller om modstand, eller rettere: om det pædagogiske arbejde med at forholde sig relevant, til den modstand børn møder gennem deres leg og engagementer i institutionens hverdagsliv. Pædagogernes fortællinger rummer, sådan som vi læser dem, en viden om, at barnets arbejde med at finde sig tilrette med sig selv og den verden, som omgiver det, kan skabe en modstand for og i barnet, som det må støttes i at gøre sig erfaringer med. Skal man tro pædagogernes fortællinger, betragtes disse erfaringer af modstand som væsentlige og essentielle, som når pædagogen Carsten i feltnoterne ovenfor ikke ser de konflikter, der opstår i forbindelse med de eftertragtede lyserøde kopper, som ubelejlige og problematiske, men som pædagogisk produktive, når børnene skal "loere noget om sig selv og om at håndtere sig selv $i$ et fcellesskab."

Modstandsbegrebet og navnlig bestræbelser på at konceptualisere børn og unges modstand har i den institutionskritiske tradition, i kritisk teori, nymarxistiske uddannelsesanalyser og frigørende pædagogik, haft en berettiget opmærksomhed. Her fortolkes modstand i relation til begreber om dominans og magt, kamp og frigørelse (Giroux, 1983; Øksnes \& Samuelsen, 2017a). Den pcedagogiske betydning af den modstand børn møder har imidlertid været noget underbelyst i den pædagogiske teori og forskning. Denne artikels ærinde er at udfolde et 
pædagogisk begreb om modstand, der tager empirisk udgangspunkt i pædagogers fortællinger om praksis, og som vi fortolker og udfolder løbende med teoretisk støtte i opdragelsesfilosofisk tænkning. Vores analyser viser, at der er en betydelig kompleksitet og dynamik forbundet med den måde, pædagogerne forstår og fortolker den pædagogiske opgave, det er, at støtte børnene i at engagere sig i en verden og et fællesskab og samtidig blive sig selv (Biesta, 2015b, s. 106; Jørgensen \& Tuft, u.å.; Øksnes \& Samuelsen, 2017b), men faktisk også en egen systematik. Vi argumenterer for, at pædagogernes arbejde med og optagethed af modstand forbinder sig til en narrativ viden, det vi med Clandinin kan kalde "stories to live by" (Clandinin, 2016). Stories to live by er ikke tilfældige udtryk for skiftende tendenser i tiden. De har tværtimod resonans i kulturelt overleverede pædagogiske narrativer om betydningen af at arbejde med barnets vilje, bl.a. formuleret af Hedevig Bagger ved den danske børnehavetraditions vugge. I disse narrativer kan vi udlæse et begreb om myndigblivelse, der har som grundtone, at barnet bliver i stand til at ville sin vilje. Vi bruger begrebet myndigblivelse, fordi pædagogerne lægger vægt på at skabe rum for, at barnet bliver aktør i sin egen opdragelse, at det myndiggør sig selv. Vores analyser af pædagogernes fortællinger peger på, at pædagoger opererer med en fortolkning og forståelse af daginstitutionens praksis, der er i samklang med Dagtilbudslovens brede formål om opdragelse til demokrati og selvstændiggørelse - formål, der i tidens massive politiske og styringsmæssige fokus på læring og læringsudbytte, synes noget oversete.

\section{Forskningstilgange og metoder}

I det forskningsprojekt, som danner grundlag for artiklens analyser og argumenter, har vi arbejdet med en hermeneutisk og fænomenologisk forskningstilgang. Vi har i udgangspunktet antaget, at pædagoger gennem deres handlinger tager del i en fortolkende social praksis, en samtale om man vil (Gadamer, 2004), der rummer en viden om og kriterier for god pædagogik. En betydelig og betydningsfuld del af den pædagogiske faglighed baserer sig i denne forståelse ikke på kriterier om sandhed og entydighed, men har snarere moralsk karakter og står derfor også altid til diskussion. At pædagogers viden (også) må forstås som en praktisk og moralsk viden, er ikke noget, vi har fundet på til lejligheden. Det er en veletableret indsigt i den ånds- og handlingsvidenskabelige tradition, der griber tilbage til bl.a. Aristoteles, Kant, og Dilthey, som historisk har kæret sig om spørgsmålet om opdragelse.

Gert Biesta, der netop betoner, at pædagogik er en praksis, der altid indebærer normative vurderinger og valg (Biesta, 2015f), kan ses som en arvtager i den åndsvidenskabelige tænkning (Biesta, 2015c, 2015d). Han har, sammen med fænomenologen Max van Manen, været en væsentlig inspirationskilde for projektets tænkning. Van Manen peger netop på at: "Pedagogy is the ability of actively distinguishing what is good from what is not good" (van Manen, 2015, s. 5). Vi har søgt at forstå denne"ability of actively distinguishing what is good from what is not 
good" med inspiration fra socio-narrative teoridannelser (Clandinin, 2016; Frank, 2012; Garro \& Mattingly, 2000) som en narrativ viden, det Clandinin kalder "stories to live by". Med Clandinins begreb om viden som "stories to live by", kan vi få blik for, hvordan moralsk og praktisk viden er retningsgivende i den forstand, at den "fortæller" og har betydning for, hvordan pædagoger forstår - eller kan forstå og fortolke - når de står i komplekse situationer, hvor der skal træffes valg. I et narrativt perspektiv kan en sådan retningsgivende viden ikke afskrives som ren subjektivisme eller som mystiske egenskaber ved personen. Den må snarere ses som intersubjektiv, social og kulturelt overleveret. ${ }^{1}$ I det perspektiv er det væsentligt og betydningsfuldt, at den drages frem, bringes i spil og udlægges, sådan at samtalen om den, om god pædagogik, kan holdes levende og åben.

I en bestræbelse på at komme på sporet af pædagogernes "stories to live by" har vi arbejdet tæt samarbejde med pædagoger og ledere i 5 daginstitutioner. Hen over foråret 2016 har vi besøgt institutionerne og organiseret det, vi kalder fortoellerum, hvor vi sammen med pædagogerne har undersøgt og udforsket pædagogernes egne fortællinger om, hvordan de konkret har handlet i deres praksis (Togsverd, Jørgensen, Rothuizen, \& Weise, 2017).

Fortællingerne og fortællerummene er vores tilgang til at undersøge pædagogernes orienteringer, forstålser og fortolkninger af, hvad der i daginstitutionspædagogikken er "det gode", "det væsentlige" og "det rigtige". Man kan sige, at vi gennem fortællerummene har søgt at komme på sporet af, men også åbne for samtaler om, pædagogernes viden om og kriterier for god pædagogik. Uden at vi dermed forudsætter at god pædagogik altid foregår eller er en entydig størrelse. Med vores hermeneutiske og narrative forskningstilgang er enhver forståelse af virkeligheden sproglig og dermed også en fortolkning. Ved at udfolde fortolkninger narrativt, indgår pædagogerne og vi som forskere i en samtale, der muliggør anderledes forståelser, andre vurderinger, kritik og nye erfaringer (se også Rothuizen, 2015, afs. 3.3.3. samt 4.1. og 4.2). ${ }^{2}$

Fortællerummene har været afviklet forskelligt, men typisk har vi hen over 3 måneder mødtes med 3-6 pædagogiske medarbejdere i en times tid hver 14. dag på personalestuen, hvor vi så har lyttet til og drøftet fortællingerne. Pædagogernes fortællinger har været meget forskellige. Nogle har været lange og beskriver samspil og handlinger, der er foregået over flere timer eller dage. Andre beskriver små korte samspil. Nogle fortællinger beskriver situationer, pædagogen oplever, er gået godt. Andre situationer, hvor pædagogen er i tvivl, eller ligefrem synes der er et stykke vej til "god pædagogik". Vi lagde op til, at pædagogerne medbragte

1 Undertitlen af van Manens bog om pædagogisk takt: "knowing what to do when you don't know what to do" er netop en udpegning af pædagogers retningsgivende viden, der primært er til som viden pædagoger har - og ikke som viden for pædagoger, der er produceret af andre.

2 Vi kan således ikke vide hvad der"i virkeligheden" eller "faktisk" skete, da vores viden om virkeligheden altid er sprogligt formidlet. Den form for sandhed vi i projektet har interesseret os for er den hermeneutiske og praktiske filosofis sandhed (jf. (Aristoteles, 2004; Gadamer, 2004), dvs. hvordan pædagogerne gennem deres fortællinger indgår i pædagogikkens virkningshistorie og leder efter det rette at gøre, altså god pædagogik. 
skriftlige fortællinger, men fik i fortællerummene også præsenteret mundtlige fortællinger, som vi så noterede undervejs.

Uanset fortællingernes meget forskellige karakter, har vi arbejdet med dem på samme måde i fortællerummene: Sammen med pædagogerne har vi undersøgt, hvad det er for handlinger og valg, der er i spil i den situation, der fortælles om. Vi har undersøgt begrundelserne for pædagogens handlinger og talt om, hvad det er, der gør - eller ikke gør - at netop disse handlinger kan forstås som pædagogiske. Vi har desuden spurgt til, hvordan pædagogen vidste, hvad hun skulle gøre, altså til hvordan hun tog beslutningen om at handle, som hun gjorde. Enkelte fortællerum er optaget på diktafon og efterfølgende udskrevet, men i hovedreglen har vi taget fyldige feltnoter, hvor vi har søgt at fastholde samtaler, diskussioner og stemninger. Det er i alt blevet til et omfattende empirisk materiale bestående af over 200 fortællinger med tilhørende feltnoter, som efterfølgende er blevet analyseret. I analysen har vi søgt at komme den retningsgivende viden nærmere ved at bestræbe os på at forstå, hvad pædagogerne forstår og lægger vægt på, gennem en analytisk konstruktion af pædagogernes kriterier for "det gode" og "det rigtige". Her er bl.a. modstandstemaet trådt frem som et tema, der kan give indblik i den kompleksitet og dynamik, hvormed pædagoger forstår og fortolker deres praksis og bringer viden i spil.

\section{Modstand som paedagogisk mulighed}

Det er væsentligt at nævne, at modstand ikke er et begreb, pædagogerne selv bruger, når de taler om deres praksis. Modstand er et begreb, vi vælger, når vi skal beskrive en særlig retning eller orientering i pædagogernes fortællinger om deres handlinger, som de tillægger værdi og betydning på vejen til noget andet. Nemlig det pædagogerne beskriver som fx at blive social eller at blive mere modig, mindre hœmmet. Hvad det er, vi mener, når vi siger, at pædagogerne er optagede af modstand, træder frem i fortællingen om Viggo, som er 5 år, og som snart skal i skole. En af de pædagoger, der er sammen med ham i hverdagen, fortæller:

\footnotetext{
Nye Turmakkere

Viggo er en dreng, som ikke er scerlig fleksibel. Han vil helst have helt styr på, hvad der skal foregå og slår og sparker, når han føler sig presset. Han er derfor heller ikke scerlig vellidt i børnegruppen. Så vi arbejder med at cendre på det og har bestemt, at vi vil arbejde med skiftende turmakkere. Det letteste er, hvis han får lov at gå med bedstevennen Ole, men jeg har besluttet, at han skal gå sammen med Jonas de noeste gange.

Der er modstand fra begge drenge, så jeg beslutter at gå mellem dem. Da vi skal hjem igen, siger jeg til drengene, at nu skal de gå sammen indtil vi kommer til Brugsen, og så snakker vi om, hvordan det var. Ved Brugsen synes drengene, det er ok, og vi vaelger at gå på samme måde til toget. Ved toget synes de stadig, det er ok og resten af turen hjem til børnehaven skiftes de til at sparke til en sten på grusstien. De griner og hygger sig.
} 
Fortællingen tager det udgangspunkt, at hverdagslivet i børnehaven er konfliktfyldt for en dreng som Viggo. Pædagogen fortæller, at Viggo har det svært, opleves som meget lidt fleksibel og ikke er særlig vellidt af de andre børn. Vi får også at vide, at det letteste er at lade ham bestemme og følges med bedstevennen, når de skal på tur. Når Viggo beskrives som en dreng der ikke er særlig fleksibel, kan man godt læse det som en institutionel kategorisering (Gulløv \& Bundgaard, 2005; Palludan, 2005), og man kan i forlængelse heraf blive bekymret for de relationer og handlemuligheder, Viggo tilbydes. Vi kan ikke vide, om det er sådan for Viggo. Men vi læser det sådan, at pædagogen, der fortæller om ham, formidler en konkret pædagogisk bekymring for, hvordan det går for ham med at finde sig en måde at være i verden. Kan han, uden at ville det, komme til at blive fastholdt i en måde at være i verden, hvor han kommer til at gøre skade på relationerne til de andre børn og dermed også på sine egne handlemuligheder? Fortællingen handler om, at pædagogen ikke vil stille sig tilfreds med tingenes tilstand. I den efterfølgende samtale om fortællingen siger hun, at før har det måske været lettest bare at lade ham gå med Ole, "fordi så vidste vi at det ville gå godt. Men det loerer han jo ikke noget af. Det er jo faktisk at suigte ham." Så i stedet for at rydde modstanden af vejen for Viggo og de andre børn, handler fortællingen om, hvordan hun rammesætter en helt almindelig hverdagsaktivitet, at børnehaven skal på tur, sådan, at der bliver skabt en smule modstand for Viggo og de andre børn.

Her kommer en anden fortælling, hvori en pædagog er optaget af, hvordan barnet kan støttes i sit møde med modstand:

\begin{abstract}
At rumme
De store børn havde voeret $i$ den gamle by hele dagen og det havde voeret sådan en dejlig tur, og de havde oplevet alt muligt og på vej hjem, så går jeg med Jens og foran ham, går en flok piger. Det er en flok piger, der altid synger $i$ bussen for eksempel, og han kan bare ikke have det, så tager han sådan hoenderne op til hovedet, op til ørerne, og så kan man bare SE vreden $i$ hans ansigt. Hans øjne bliver helt sorte. Og så skulle han selvfølgelig gå lige der bag dem, og trunterne begynder at synge. Og han bliver mere og mere ... Men jeg toenkte, at det skulle de have lov til, de gjorde intet galt, og de var glade og solen skinnede og fuglene sang. Og Jens' øjne blev sortere og sortere. Så jeg talte med ham om det. Jeg sagde til ham, at jeg godt vidste, at det er svoert for ham at klare det, at han noesten ikke kunne, men at de bare var glade. "Prøv engang at toenke på noget du synes er rart", sagde jeg så. "Prøv at morke vinden $i$ ansigtet og at du går her med mig, du må gerne holde mig $i$ hånden. Troek vejret helt ned i maven." Og jeg kunne se, at han ligeså stille lukkede øjnene og trak vejret, og så gik vi der, og så fungerede det fint.
\end{abstract}

Fortællingerne om Viggo og Jens kan på en og samme tid læses som beskrivelser af konkrete handlingsforløb, fortalt og oplevet af pædagogen, og som spørgsmål til om disse handlingsforløb, nu også var udtryk for god pædagogik. Dramaet i fortællingerne er stort, og vi, der lytter eller læser, mærker, at meget er på spil, og vi følger med, spændte på, hvordan det skal gå. I fortællerummet mærker vi, at pædagogen i situationen har fulgt med på samme måde - i spænding. Hun har fortolket situationen og barnet og træffer hurtigt et valg ud fra en forestilling om, 
at hendes handlinger vil føre til god pædagogik. Men hun kan ikke vide, om det også vil gå, som hun håber.

\section{At flytte sig ind i verden}

Helt grundlæggende kan man læse de to fortællinger, som fortællinger om pædagogernes arbejde med at støtte barnet i at engagere sig i og gå i dialog med en verden, som det på en og samme tid er en del af og forskellig fra. Fortællingerne er beretninger om måder, hvorpå børn, med et begreb Hans-Georg Gadamer bruger, flytter sig ind i verden (Gadamer, 2000). Vi fortolker fortællingerne sådan, at pædagogerne har en viden om og forventning til, at børnene i deres møde med verden, dens ting, relationer og fænomener, vil møde noget, der har karakter af en grundlæggende andethed. Verden er andethed, fordi den har en egen eksistens, form og væren, som er forskellig fra barnet, og som ikke nødvendigvis er som barnet ønsker (Biesta, 2012, 2015b, s. 113). Nogle gange stiller noget sig i vejen for barnet, for dets umiddelbare behov og lyst. Og det er netop dette møde med andethed, og den modstand det skaber i og for barnet, som på en og samme tid skaber et lille drama, og noget pædagogerne, ifølge fortællingerne, opfatter som en pædagogisk mulighed og forpligtelse.

Gert Biesta beskriver, hvordan man kan møde andethed i verden på tre måder: man kan gøre vold mod det; man kan trække sig fra det; eller man kan arbejde med at finde en måde at komme overens med det på. I sit møde med verdens andethed balancerer barnet - med Biestas begreber - mellem verdensdestruktion og selvdestruktion (Biesta, 2012, 2015b, s. 113; Øksnes \& Samuelsen, 2017b). Pædagogernes fortællinger og deres udlægninger af dem peger på, at de mener, at pædagogikken må yde sit i denne balancegang. Med Biestas begreber kan vi analytisk forstå fortællingerne som en optagethed af, hvordan pædagogen kan bidrage til, at barnet selv kan bevæge sig i og udvide zonen imellem det at gøre vold på verden og at gøre vold på sig selv. Fortællingerne synes at rumme en viden om, at det er betydningsfuldt, at barnet øver sig i at bevæge sig i mellemzonen. Og at det herigennem udvider sine muligheder og sit handlerum.

Hermed knytter fortællingerne sig til et narrativ, som allerede blev formuleret ved den danske børnehavetraditions vugge, og som handler om den pædagogiske betydning af at arbejde med barnets vilje. Hedevig Bagger, der i 1880 oprettede en børnehave og i 1885 udbød det første uddannelseskursus for børnehavelærerinde, skrev i 1891: "Efter vor Erfaring er intet barn saa ulykkeligt som det, der ingen Vilje har over sin Egen” (H. Bagger, 1891 s. 112). Med Biesta kunne man sige, at er man i sin viljes vold, ja så kan det føre til verdensdestruktion eller selvdestruktion. Derfor handler pædagogik om at kultivere viljen, blandt andet ved at give barnet erfaringer med modstand (Meirieu, 2008). Vi finder det interessant og væsentligt, at daginstitutionspædagoger i dag ser ud til at være optagede af samme tema, og at et pædagogisk narrativ om arbejdet med barnets vilje, fortsat ser ud til at være aktuelt og relevant i daginstitutionernes praksis. Mange af 
pædagogernes fortællinger om modstand handler netop om at lære at dele, om at give sig for at kunne få tilbage, og pædagogerne bruger ofte formuleringer som "at blødgøre" eller at "bøje og strckke viljen", når de beskriver deres arbejde med børn, der vurderes at være så fokuserede på sig selv, at de bliver ufri.

\section{Magt, men også takt}

Når vi ser på tværs af fortællingerne, kan vi se, at de gennemgående har samme dramatiske plot, omend i mange forskellige variationer. Plottets grundlæggende konflikt kan analytisk forstås, som en resonans af det Kant formulerede som det pædagogiske problem:"Hvordan kultiverer jeg friheden, hvor der er tvang?"(Kant, 2000, s. 35). Fortællingerne tyder ikke på, at pædagogerne ser børnenes erfaringer af modstand og magt som noget, man kan eller skal undslippe. Som vi analyserer fortællingerne, ser pædagogerne tvangen som et vilkår, man skal komme overens med, som noget der kalder på, at barnet udvikler sig og tilegner sig nye forholdemåder. For pædagogerne er der pædagogiske muligheder i modstanden. Som vi fortolker pædagogens fortælling om Jens med de sorte øjne, rummer den en morale og viden om, at Jens ikke bliver et frit og myndigt menneske af, at pædagogen beder pigerne skrue lidt ned, eller af at hun flytter ham et andet sted hen. Pædagogen fortæller i den efterfølgende samtale, at hun vurderede, at det kunne være væsentligt for ham, at gøre sig nogle erfaringer med at udholde pigernes sang. Formuleret teoretisk kan man sige det sådan, at hun gennem sine handlinger søger at vise ham, hvordan han kommer overens med pigernes andethed og dermed også med sin egen vilje. Kan han dét, vil han, som vi forstår pædagogens tænkning, gøre sig nogle nye erfaringer med at komme overens med både sig selv og sin omverden. Måske overskrider han både sig selv og den aktuelle sociale orden og bliver herigennem mere fri.

Fortællingen om Jens med de sorte øjne rummer, som vi læser den, en morale om, at det er en central pædagogisk opgave at give børn erfaringer med modstand, sådan at de kan gøre sig erfaringer med deres egen vilje. I de efterfølgende samtaler, hvor pædagogerne selv har haft mulighed for at udlægge fortællingerne og deres egne handlinger, kan vi imidlertid også se en opmærksomhed på og omsorg for, at tvang og modstand balanceres og doseres taktfuldt og omhyggeligt (Manen, 2015). Pædagogen fortæller efterfølgende, at hun ville hjælpe ham til at finde ud af at være i situationen, men også at hun "hele tiden kiggede på om han kunne klare det". I den samtale, pædagogerne og vi har om fortællingen om Viggo, fortæller pædagogen, at situationen faktisk var meget planlagt. Hun fortæller, at hun f.eks. havde tænkt meget over, at hendes rammesætninger kun var rimelige, hvis der blev opstillet nogle små overskuelige mål for Viggo, men også for Jonas. Hun fortæller, at hun vælger at begynde med at gå imellem drengene og med sin krop, for på en og samme tid at skærme dem fra hinanden, men også bringe dem nærmere hinanden. På hjemturen, da drengene har oplevet, at det gik godt, fortæller pædagogen, at hun skaber en ny rammesætning, idet de får til opgave at 
gå sammen uden hendes krop imellem sig. Men opgaven brydes op i små bidder i en bestræbelse på at imødekomme den bekymring, drengene måtte have, og den risiko gåturen bliver for dem. Pædagogen fortæller, at hun gør det for at gøre opgaven overskuelig. "De ved at det bare er hen til Brugsen, så har de klaret det", siger hun. "Men så kan de også sige fra, hvis det bliver for svoert."

\section{Subjektificering og civilisering}

Vi kan nå en ny forståelse af pædagogernes optagethed af balancen mellem tvang og frihed og det at danne viljen, ved analytisk at interessere os for de formål og processer, pædagogerne synes optagede af i deres fortællinger om modstand; om hvordan børns oplevelser af modstand kan mødes; og om hvordan modstand kan få betydning. I det følgende argumenterer vi for, at modstandstemaet og arbejdet med at danne viljen, kan forbindes til et dobbelt formål, som også kan konstrueres i pædagogernes fortællinger. Analytisk forstår vi dem som to forskellige mål, der både betinger hinanden og udgør et spændingsfelt, to sider af samme mønt. Det ene kalder vi subjektificering, det andet civilisering.

Hvor vi bruger subjektificering for at betegne, at pædagogerne er optagede af at se barnet som unikt, som en ny begyndelse der i sit samspil med verden gerne skulle finde og videreudvikle sin egen måde at være i verden på, så bruger vi begrebet civilisering for at pege på, at pædagogerne, som vi analyserer deres fortællinger, også ser daginstitutionspædagogikken som et civilisatorisk projekt. Når pædagogerne udlægger deres praksis, synes de ikke alene at være optagede af det unikke barn og dets tilsynekomst - de er også optagede af at skabe muligheder for, at der opstår fællesskaber, hvori der er plads til anderledeshed; fællesskaber der rummer forpligtelser over for det og de, der er anderledes end os selv (Ziehe, 2004). Tænk eksempelvis på fortællingen om Jens med de sorte øjne. Det civilisatoriske projekt kan forstås som et utopisk projekt, der drejer sig om at skabe et samfund af frie borgere, som besinder sig på at indgå i forpligtende fællesskaber. Pædagogerne er altså både optagede af, at det unikke barn skal komme til syne i samspillet med verden (subjektificering) og af at skabe forpligtende fællesskaber, der består af frie borgere (civilisering). ${ }^{3}$ Ved at bruge de to begreber subjektifi-

$3 \quad$ Vores brug af begrebet adskiller sig fra kritisk teori, som opererer med et socialisationsbegreb, der efter vores mening ikke i tilstrækkelig grad kan fange det civilisatoriske, der på en gang indebærer en videreførelse og en overskridelse af verden. Endelig adskiller vores civiliseringsbegreb sig fra den måde det bruges på i Norbert Elias civiliseringsteori der i dansk sammenhæng er taget op af Eva Gulløv og Laura Gilliam i en undersøgelse af danske daginstitutioners civiliseringspraksisser. Her betones og analyseres civilisering, med inspiration fra Elias, som kulturelt specifikke distingveringsprocesser der gennem forestillinger om det civiliserede barn (til forskel fra det uciviliserede barn) også etablerer kulturelle og sociale distinktioner (Gilliam, Laura; Guløv, 2012). Vi har ikke været optagede af sådanne distinktionsog dominansaspekter ved opdragelse. Man kan sige at vi med vores civiliseringsbegreb lægger lidt til eller måske rettere ekspliciterer dele af subjektificeringsbegrebet hos Biesta, som let kan overses. Ved at bruge to begreber, subjektificering og civilisering, lægger vi os i forlængelse af Immanuel Kant for hvem det pædagogiske moraliseringsprojekt også var forbundet med et civiliseringsprojekt (Kant, 2000) og i sidste ende med idealet om verdensborgerskab. 
cering og civilisering som mål og processer, der er som to sider af samme mønt, søger vi at pege på, at de hænger sammen. Men vi gør det også muligt analytisk at få blik for dem som forskellige dimensioner, og altså give blik for en spænding og kompleksitet, i pædagogernes forståelser, fortolkninger og forvaltninger af deres praksis.

\title{
Det paedagogiske projekt: at overskride det eksisterende
}

Før vi illustrerer dette dobbelte formål yderligere med en fortælling, skal endnu en analytisk pointe nævnes. Pædagogernes fortællinger har i vores fortolkning den gennemgående morale, at det er god pædagogik at forstå og fortolke barnets opgave med at møde det andet som et møde i ordets egentlige forstand. Det er ikke simpelt sådan, at barnet skal underlægge sig fællesskabet. Tværtimod rummer en del af pædagogernes fortællinger en morale om, at der gerne må ske en overskridelse, både i barnet og med den verden, det indgår i og skal komme overens med. Hvad der konkret er i spil, kan illustreres med en fortælling:

\begin{abstract}
Jonathans skal-opgave
Den handler om Jonathan, som er en forsigtig dreng $i$ mellemgruppen. Han er ikke så modig, og så hader han bare, de der skal-opgaver. Han synes altid, de er svoere, fordi de tit handler om at gøre noget, man synes er lidt farligt, og det er han ikke meget for. For eksempel skulle de prøve en svoevebane engang, og han er godt nok ikke meget for det, men han gør det, han arbejder med det. Men han spørger altid: "er der skal-opgaver?" og hvis man så siger at det er der ikke, så bliver han så lettet simpelthen. Det skal vi have snakket om, sådan skal han jo ikke have det! Nå men, vi er på stranden, og han har taget skoene af og står med toeerne $i$ vand. Vandet når langt op ad benene på ham. Jeg spørger ham, om ikke det er koldt? "Jo" siger han og smiler. Tonker lidt og siger så: "det ville vcere en god skal-opgave!" "Ville det det?" Spørger jeg og griber ideen. "Skal vi så ikke sige til de andre, at de skal prøve det? Vil du sige det?" Det er Jonathan med på. Så vi står alle på roekke, og jeg står med Jonathan ved siden af mig og siger, at han har en skal-opgave. Og så står han der og fortceller, højt og tydeligt, at alle skal tage skoene af og hoppe $i$ vandet $i$ kanten.
\end{abstract}

I fortællingen hører vi, at pædagogerne i Jonathans børnehave har indført skal-opgaver, og i en anden sammenhæng fortæller de os, at de gør det for at give børnene erfaringer med også at møde og øve sig i noget, de ellers ikke ville kaste sig ud i. I pædagogens fremstilling hører vi også om Jonathan, og at netop han har det svært med skal-opgaverne. Han er "godt nok ikke meget for det, men han gør det, han arbejder med det", fortæller pædagogen.

Jonathan fremstilles som et unikt barn, sin helt egen, med sin vilje, som på den ene side skal respekteres og på den anden side også har brug for modstand, for at han kan udvikle sig, sådan at hans vilje og måder at møde verden på bliver et aktiv for ham. Pædagogen fortæller, at han er lidt forsigtig, og det underforstås, at lidt mere mod ville være ensbetydende med et større og friere handlerepertoire. Men sådan som vi læser fortællingen, rejser den også en tvivl. Bliver modstanden i skal-opgaverne for stor for Jonathan? Får modstanden ham til at trække sig lidt? 
Gør skal-opgaverne hans forsigtighed større? "Det skal vi have snakket om", siger pædagogen, "sådan skal han jo ikke have det"

I fortællingen sker der imidlertid noget. Jonathan tager et initiativ og får en idé til en skal-opgave, og ifølge fortællingen griber pædagogen den. Dette moment er i vores læsning af fortællingen afgørende. Jonathan går i fortællingens drama fra at være et objekt for pædagogernes udpegninger af skal-opgaver, til at træde frem som et subjekt. En helt særlig og selvstændig én, som kommer til syne, både for sig selv, for pædagogen og de andre børn. Vi ser det sådan, at der, med fortællingen, føjes flere perspektiver til fortolkningen af Jonathan. Pædagogen får øje på, at han faktisk kan være ganske modig. Analytisk kan vi forstå fortællingen som et narrativ om, at Jonathan subjektificerer sig, og bliver en helt særlig person, netop fordi pædagogen griber muligheden, og understøtter ham i at træde frem. Fortællingen kan læses som en fortælling om en pædagog, der får øje på nye sider af en dreng. Men den kan også læses som en fortælling om en dreng, der tager del i børnehavens fællesskab og den offentlighed, der knytter sig hertil, på en måde, som netop pga. Jonathans handlinger bliver et andet. Fortællingen handler om subjektificering og civilisering som to sider af samme mønt, fordi det både er Jonathan, der forandrer sig, overskrider sig selv og bliver mere myndig, og fællesskabet, der får føjet til repertoiret. Vi læser således også fortællingen som en fortælling om, at både børnene og pædagogen får den erfaring, at sådan her kan man også lave skal-opgaver: de kan bestemmes af børnene selv.

Analytisk læser vi fortællingen om Jonathan, som en af mange fortællinger, der handler om hvordan pædagogerne finder det betydningsfuldt at balancere subjektificering og civilisering som to sider af samme mønt, snarere end at vælge imellem dem. Flertydigheden er netop ikke en fejl, men et vilkår, en del af det pædagogiske projekt, kunne man sige. I de tre fortællinger kan vi analysere os frem til begge perspektiver, og selvom der er tale om pædagogiske mål, der trækker i hver sin retning, forudsætter de også hinanden. Ligesom andethed er en forudsætning for subjektets tilblivelse i form af en selvoverskridelse. Subjektificering og civilisering angiver dobbeltheden i opgaven: der skal skabes et forpligtende fællesskab, men det skal meget gerne foregå på en måde, som samtidig understøtter og respekterer den enkeltes frihed gennem en taktfuld opfordring til barnet til selv at finde sin vej. Derigennem kan barnet overskride det, der er. Det overskrider sig selv ved at realisere en ny og villet mulighed, men det bidrager også til en overskridelse af gængse samværsformer i retning af forpligtende fællesskaber, der kan rumme anderledeshed. Vores analyser af pædagogernes fortællinger og af den viden om god pædagogik, de rummer, peger på at pædagogerne ser pædagogikken som en kompleks udfordring, der handler om at skabe tilpasning og regulering til et fællesskab på en måde, der nok bevæger, men ikke krænker det enkelte barn og dets vilje. Som vi læser det, har også dette resonans i den danske børnehavetradition, hvor den reformpædagogiske bevægelse netop var optaget af et politisk projekt, som knytter sig til dannelsen af det gode og demokratiske samfund (se Tuft, 2017). 


\section{Udvikling af viljen handler om myndigblivelse}

På baggrund af vores analyser mener vi, at kunne udlæse et daginstitutionspædagogisk begreb om myndigblivelse, der ikke er koblet til en forestilling om fornuft, der har sandhed som sit kriterium, eller som noget foruddefineret, der kan læres. Der er snarere tale om et opdragelsesideal, som er knyttet til en forestilling om viljen; en fornuft der, som Aristoteles allerede udtrykte det, har som sit kriterium at det gode bliver gjort (Aristoteles, 1998, 2000). Myndighed, at blive et myndigt væsen, handler i pædagogernes fortællinger om at have en rettethed, en villet vilje, eller som Gert Biesta udtrykker det: om at mennesket bliver i stand til at afklare hvilke ønsker, der er ønskværdige (Biesta, 2012, 2015a). Myndighed handler dermed om en selvdannelse, der samtidigt er en selvbegrænsning, eller rettere sagt: om en befriende selvbegrænsning (se også Meirieu, 2008). Moralen i ganske mange af pædagogernes fortællinger er, at selvbegrænsningen - at have en villet vilje - blandt andet kommer af, at man gør sig erfaringer med at møde modstand. At man støder sig på verden; gør sig erfaringer med en verden, der står i vejen for den spontane vilje; og at man finder ud af, at den spontane vilje derfor må transformeres til en villet vilje. En verden der ikke føjer sig, der ikke er en forlængelse af egoet, der repræsenterer andethed og derved "står i vejen", er altså paradoksalt nok forudsætningen for, at selvet dannes. Som vi analyserer pædagogernes fortællinger, ser pædagoger det som deres opgave at gå ind i den dynamik, at følge og skabe børns møder med andethed, at rammesætte og følge børnenes egne dannelsesprocesser og gøre en pædagogisk indsats i forhold til disse. Den pædagogiske indsats er blandt andet at yde modstand, dvs. at udøve magt. For eksempel ved at købe krus af forskellige farver.

Som vi læser pædagogernes fortællinger, kan arbejdet med at danne viljen hverken forstås som en børnecentreret tilgang (selvom den tager udgangspunkt i det unikke barn), eller en tilgang, der er orienteret omkring læreplanstemaer og færdigheder, børnene skal dygtiggøre sig i. Vores analyse viser, at når pædagoger gennem fortællinger afsøger og orienterer sig mod "god pædagogik", så er de optagede af på en og samme tid at støtte og bevœge børnenes måder at være i verden på. Vi fortolker det sådan, at de er optagede af hvordan børnene, med Gadamers ord, "flytter sig ind i verden" og bliver selvstændige mennesker, der kan udøve deres myndighed i en verden, de bebor sammen med andre. Og her er pædagogerne helt i tråd med det samfundsmæssige mandat, som historisk og aktuelt, er beskrevet i de centrale politiske dokumenter vedrørende daginstitutionerne. I den aktuelle Dagtilbudslov kan man i formålsparagraffen, $§ 7$ stk. 4, læse at:

Dagtilbud skal give børn medbestemmelse, medansvar og forståelse for demokrati. Dagtilbud skal som led heri bidrage til at udvikle børns selvstcendighed, evner til at indgå $i$ forpligtende foellesskaber [...] (Dagtilbudsloven. Bekendtgørelse af lov om dag-, fritids- og klubtilbud m.v. til børn og unge, 2016) 
Selvom det måske ikke er den opgave, der for tiden tiltrækker sig den største politiske opmærksomhed, så er pædagogerne optagede af den. Når man ind imellem kan høre, at pædagoger udviser en vis forsigtighed m.h.t. at forskyde balancen mellem daginstitutionslivets forskellige aktiviteter og organisationsformer, eksempelvis i form af flere planlagte pædagogiske aktiviteter med et specifikt læringsformål (Danmarks Evalueringsinstitut, 2016, 2017), kunne det netop hænge sammen med, at pædagogerne forstår og fortolker arbejdet med børnenes måde at være i verden på, med civilisering og subjektificering, som grundlæggende og betydningsfuld. Det er derfor også selve samværet, der er det pcedagogiske objekt (for lignende fund, se Gilliam og Gulløv, 2012, s. 63).

Pædagogerne peger med deres fortællinger på at barnets "flytten sig ind i verden" foregår i alle situationer, og at det hverken kan planlægges i detaljer, foruddefineres eller forudses. Derfor kan man også læse pædagogernes fortællinger som en betoning af daginstitutionens hverdagsliv som et øverum for børnene, der netop har værdi og betydning som et rum, der er afskærmet alverdens krav og målsætninger. Netop sådan at det er muligt at øve sig (Biesta, 2015e)turning them into democratic citizens, or bringing about a cohesive and inclusive society. What unites such expectations is that they all approach the school as a kind of instrument for solving societal problems. In sociological language we could say that the school is treated as a function of society and thus as an institution that should be functional (and useful. Den franske pædagog Philippe Meirieu knytter i sin bog om modstand to "pligter til at yde modstand" sammen: 1) et pædagogisk miljø er kendetegnet af, at børn udsættes for modstand og af, 2) at der ydes modstand mod samfundets forventninger og krav om, at "god pædagogik" er pædagogik, der leverer på prædefinerede (lærings)mål (Meirieu, 2008; sml. også Mollenhauer, 1977; Rømer, Tanggaard, Brinkmann, \& (red), 2011). Lasse Dencik var inde på en lignende pointe, da han i 1992 skrev en artikel om "Modstandens pædagogik":

Måske er det slet ikke først og fremmest gennem ordnede indsatser som f.eks tilrettelagte poedagogiske forløb og planlagte uddannelsesforløb, at mennesker kan kvalificeres til at fungere adcekvat $i$ det samfund de lever $i$. Måske er det så enkelt og lykkeligt, at livet selv, er livets bedste skole (Dencik, 1992).

Måske knytter pædagogernes betoning af de pædagogiske muligheder, der ligger i daginstitutionens hverdagsliv, sig an til en simpel og banal, men alligevel uhyre vigtig pointe: pædagogerne ved, at de ikke kan vide, hvad fremtiden bringer, og hvad der skal til, for at barnet kan klare sig og skabe mening i en ukendt fremtid. I et sådant perspektiv fremmer arbejdet med modstand, og det at danne viljen, at børn udvikler sig i en retning, der kan hjælpe dem til fremover at forlige sig med, men også omforme det, der stiller sig anderledes som bump på vejen. 


\section{Litteratur}

Aristoteles. (1998). Nikomachische Ethik VI. (H.-G. Gadamer, Red.). Frankfurt am Main: Klostermann.

Aristoteles. (2000). Etikken. Frederiksberg: Det Lille Forlag.

Aristoteles. (2004). Poetikken. (N. Henningsen, Red.). Frederiksberg: DET lille FORLAG.

Biesta, G. (2012). The Educational Significance of the Experience of Resistance: Schooling and the Dialogue between Child and World. Other education: The Journal of Educational Alternatives, 1(92-103).

Biesta, G. (2015a). Freeing Teaching from Learning: Opening Up Existential Possibilities in Educational Relationships. Studies in Philosophy and Education, 34(3), 229-243.

Biesta, G. (2015b). Hvad skal vi stille op med børnene? Om uddannelse, modstand og dialogen mellem barn og verden. I J. Klitmøller \& D. Sommer (Red.), Laring, dannelse og udvikling. Kvalificering til fremtiden $i$ daginstitution og skole. Hans Reitzels Forlag.

Biesta, G. (2015c). On the two cultures of educational research, and how we might move ahead: Reconsidering the ontology, axiology and praxeology of education. European Educational Research Journal, 14, 11-22. https://doi.org/10.1177/1474904114565162

Biesta, G. (2015d). Teaching, Teacher Education, and the Humanities: Reconsidering Education as a Geisteswissenschaft. Educational Theory, 65(6), 665-679. https://doi.org/10.1111/edth.12141

Biesta, G. (2015e). The duty to resist: Redefining the basics for today's schools 1. RoSE -Research on Steiner Education, 6, 1-11. Hentet fra www.rosejourn.com

Biesta, G. (2015f). What is Education For? On Good Education, Teacher Judgement, and Educational Professionalism. European Journal of Education, 50(1), 75-87. https://oi.org/10.1111/ ejed.12109

Clandinin, J. (2016). Engaging in Narrative Inquiry. London: Routledge.

Cleary, J., \& Hogan, P. (2001). The reciprocal character of self-education: introductory comments on Hans Georg Gadamer's address 'Education is self-education. Journal of Philosophy of Education, 35(4), 519-527.

Dagtilbudsloven. Bekendtgørelse af lov om dag-, fritids- og klubtilbud m.v. til børn og unge, LBK nr. 748 af 20/06/2016 (2016).

Danmarks Evalueringsinstitut. (2016). Organisering af et godt loringsmiljø. Hentet fra https:// www.eva.dk/projekter/...organisering-af...i.../organisering...godt.../download\%0A\%0A

Danmarks Evalueringsinstitut. (2017). Kvalitet $i$ dagtilbud -pointer fra forskning. København. Hentet fra https://www.eva.dk/projekter/2016/forstaelse-og-maling-af-kvalitet-i-dagtilbud/ hent-udgivelser/kvalitet-i-dagtilbud-pointer-fra-forskning/view

Dencik, L. (1992). Modstandens pædagogik. Dansk pcedagogisk tidsskrift, 4, 158-166.

Frank, A.W. (2012). Letting stories breathe - a socio-narratology. Chicago: The University of Chicago Press.

Gadamer, H.-G. (2000). Erziehung ist sich Erziehen. Heidelberg: Kupfeldischer Verlag.

Gadamer, H.-G. (2004). Sandhed og metode. Grundtrcek af en filosofisk hermeneutik. Aarhus: Systime Academic.

Garro, L.C., \& Mattingly, C. (2000). Narrative as Construct and Construction. Narrative and the Cultural Construction of Illness and Healing, (29), 1-49. https://doi.org/10.1525/california/9780520218246.001.0001

Gilliam, Laura; Guløv, E. (2012). Civiliserende institutioner. Om idealer og distinktioner i opdragelse. Århus: Aarhus Universitetsforlag.

Giroux, H.A. (1983). Theory and Resistance in Education. South Hadley: Bergin \& Garvey.

Gulløv, E., \& Bundgaard, H. (2005). Forskel og fallesskab. Minoritetsbørn i daginstitution. København: Hans Reitzels Forlag.

Jørgensen, H.H., \& Tuft, K. (u.å.). Forskrifter for god pcedagogik. Om viden, fagsprog og forskningsmetoder i pcedagogers profession. København: Akademisk Forlag.

Kant, I. (2000). Om pcedagogik. Aarhus: Klim. 
Manen, M. van. (2015). Pedagogical tact. Knowing what to do when you don't know what to do. Walnut Creek, California: Left Coast Press.

Meirieu, P. (2008). Pédagogie : le devoir de résister. Issy-les-Moulineaux: ESF éditeur.

Mollenhauer, K. (1977). Erziehung und Emanzipation. Polemische Skizzen. München: Juventa Verlag.

Palludan, C. (2005). Børnehaven gør en forskel. København: Danmarks Pædagogiske Universitetsforlag.

Rothuizen, J.J. (2015). På sporet af pcedagogisk faglighed. Poedagoguddannelsens deltagelse $i$ det pcedagogiske projekt. Aarhus University, DPU. Hentet fra https://viauc.academia.edu/janjaaprothuizen

Rømer, T.A., Tanggaard, L., Brinkmann, S., \& (red). (2011). Uren Pcedagogik. (T.A. Rømer, L. Tanggaard, \& S. Brinkmann, Red.). Aarhus: Klim.

Togsverd, L., Jørgensen, H.H., Rothuizen, J.J., \& Weise, S. (2017). Viden $i$ spil $i$ daginstitutioner. Aarhus: DPP. Findes også på kortlink.dk/ucviden/qedb

Tuft, K. (2017). Pædagogik - Opdragelse. Frihed og demokrati. Kausalitet og totaliserende elementer. Forskning $i$ Podagogers Profession og Uddannelse, 1(2).

Ziehe, T. (2004). Øer af intensitet $i$ et hav af rutiner. København: Politisk Revy.

Øksnes, Maria; Samuelsen, M. (2017). “Nej, jeg gjør det på min måte!”. Motstand i barnehagen. I Motstand. Oslo: Capellen Damm.

Øksnes, M., \& Samuelsen, M. (2017). The encounter with resistance is an existential matter. Interview with Gert Biesta. I Motstand. Oslo: Cappelen Damm Akademisk. 